\title{
Role of Banking Inclusion in Reducing Poverty in Eastern Indonesian Region, Sulampua
} (KTI)

\author{
Marsuki ${ }^{1}$, Sabir ${ }^{2}$, Munawwarah S.M ${ }^{3}$ and Muhammad J.T ${ }^{4}$ \\ ${ }^{1}$ Hasanuddin University, Indonesia \\ ${ }^{2}$ Hasanuddin University, Indonesia \\ ${ }^{3}$ Hasanuddin University, Indonesia \\ ${ }^{4}$ Hasanuddin University, Indonesia
}

\begin{abstract}
This paper has the objective to understand the condition, factor determining and effect of banking inclusion program to income distribution in order to reduce poverty in a selected city in the Eastern Indonesian Region (KTI). It also analyses the banking inclusion effect on income distribution and poverty level in the regions. Banking inclusion is measured by the index, in particular, banking inclusion through banking penetration indicator, banking accessibility, and also the use of bank account. Distribution and inequality of financial and income are measured by the total growth of the poor in the respective regions. Type of this research is explanatory with qualitative approaches by using secondary data and survey in the selected city in KTI. The focuses of research analysis are analysis on banking inclusion index and analysis on relation test between banking inclusion to income distribution indicator and poverty level. Analysis method employs various analysis tools. Banking inclusion index is measured by using financial inclusion index formula. Inequality income indicator and inequality on financial sector employ, namely Gini Ratio Index, and Relation Analysis Approach employs the descriptive method. Generally, assumption put forward is that banking inclusion in the city in KTI can be still categorized in financial inclusion index, in particular, banking relatively low and unequal, except in some province which has been becoming a strategic economic hub, namely Makassar and Manado. It is caused by some structural problems, institutional, human resources, and applicable rules. The result of relation test between banking inclusion index and its inequality to economic inequality indicator, income distribution, and poverty are expected to indicate one-way relation, in which banking inclusion index affects distribution index, and subsequently affect poverty level.

Keywords: Financial and banking inclusion, Inequality income, Reducing Poverty
\end{abstract}

\section{Introduction}

Indonesia's development is still faced with problems of development inequality and poverty between regions. Progress in development in the Indonesian Western Region (KBI), especially in Java, still dominates. From 1978 to 2016, the economic contribution of the Eastern Indonesia Region (KTI) to the national economy was only around 20 percent.

Even though in recent years, the economic growth of the KTI has generally been higher than the national level, but inequality in Eastern Indonesia is among the highest because the accelerated growth has not been followed by reducing income inequality and poverty. It is reflected from the spread of underdeveloped areas in Indonesia where 80 percent are located in Eastern Indonesia. There are four fundamental issues faced by KTI which are mainly related to the economic and social fields including, the low accessibility between areas of business and trade, as well as access to financial institutions, especially banks.

Concerning this paper, so that the program "Financial Inclusion" can be one technique to find solutions to overcome the problems of income inequality and economic poverty in the KTI in particular. The reason, because it cannot be denied that one of the causes of economic inequality that is very varied and complex is because of the problem of public access to financial institutions, the main banks are still very low and concentrated only in certain regions, including in Eastern Indonesia. 
The development of banking in Eastern Indonesia is relatively good, but income inequality tends to increase and poverty rates remain high even though they have a declining trend, so this continues to be a problem in the economy in Eastern Indonesia. This raises several related questions about the role of banks in Eastern Indonesia in an effort to equalize income and alleviate poverty. Therefore it is necessary to know and evaluate the extent to which banking inclusion programs, in particular, can reduce income inequality, especially in efforts to alleviate poverty in Eastern Indonesia.

Review of Theory of Financial Inclusion in Alleviating Poverty. The concept of financial inclusion arose after the concept of financial exclusion. Various researchers define financial inclusion as the opposite of financial exclusion. Sarma (2012) defines financial inclusion as a process that guarantees the ease of access, availability, and benefits of the formal financial system for all economic actors. Bank Indonesia (2013) defines financial inclusion as all efforts aimed at eliminating all forms of price or non-price barriers to people's access to financial services. Indicators that can be used as a measure of a country's inclusive finance are availability / access to measure the ability to use formal financial services in terms of physical affordability and prices, use to measure the actual use of financial products and services (including regularity, frequency and duration of use), quality to measure whether the attributes of financial products and services have met customer needs, and welfare to measure the impact of financial services on the level of life of service users.

Beck et al. (2007) stated that the concept of access to financial services by using financial services was a different concept. Economists may have access to financial services but do not want to use them. This can be caused by socio-cultural reasons or too high offset costs for using financial services. Therefore, Beck et al. differentiate the two concepts related to the reach of the financial sector, namely (i) the existence of access and possibility in using financial services, and (ii) the use of actual financial services which means actually using financial services.

Demirguc-Kunt A et al. (2008) explain in more detail the differences in access to financial services with the use of financial services. Access is intended for supply while the use of financial services is determined by both supply and demand. Even though someone with high income has access to financial services, it is possible that he is not interested in using the service. Similarly, customers, both individuals and companies, do not necessarily want to borrow money even though they are offered low-interest rates.

Some researchers measure financial inclusion by calculating the proportion of the adult population or households that have access to formal financial services known as the Index of Financial Inclusion (IFI). Another study distinguishes the concept of access to financial services with the use of financial services. Access to financial services can be measured by the number of banking offices and the number of ATMs scattered in a region, the use of financial services is measured by the number of deposits and loans channeled (World Bank 2008).

Sarma et.al. (2011) summarizes the various thoughts in one concept, namely the Financial Inclusion Index (Index of Financial Inclusion). This index itself is used to measure the inclusiveness of the financial system in a country. The IFI calculation developed by Sarma is divided into three dimensions, namely:

1) Banking Penetration. Banking penetration is a leading indicator of financial inclusion. The more users, the better, because of that the financial system is expected to reach widely among users. One indicator of banking penetration is the proportion of the population that has an account in the bank. 2) Availability of financial services. Financial services must be available to all users, in an inclusive financial system. This measure of availability is the number of outlets (branch offices, ATMs, etc.). Availability of services can be seen from the number of branches of financial institutions or the number of ATM (Automatic Teller Machine).

3) Use of banking services. There are many reasons why a group of people still do not use financial services even though they have access to financial services. Among other things, away bank outlets from residential or daily activities, bad experiences involving service providers. Therefore, having an 
account is not enough to show an inclusive financial system, but people can also use it. These uses can include credit, deposits, payments, remittances, and transfers.

Financial Inclusion and Poverty Alleviation in Eastern Indonesia. In the case of Indonesia, the vast area and geographical conditions that have many islands, clearly leaving heavy homework to increase financial inclusion in the country quickly. In accordance with the Indonesian National Financial Literacy Survey (SNLKI), 2016, Indonesia's financial inclusion index was recorded at 67.82 percent, with the banking inclusion index 59.74 percent, but still lower than India (83\%), Thailand 98\%), and Malaysia (127\%). At present, there is still around 40 percent of the people who do not have access to banking. Based on the results of a study conducted by BI, the ratio of bank office availability in the community is still low, namely 16 offices per 100,000 residents. While the credit to GDP ratio is only 35.6 percent. This figure makes Indonesia one of the countries with the lowest credit ratio in Southeast Asia.

One of the factors that cause low financial services is the infrastructure constraints to being able to serve people in remote areas. Limited banking services to some of these areas are also inseparable from the calculation of the economies of scale of bank operations in an area. This can be seen in the indicator of the number of banking services such as branch offices and ATMs for every $1000 \mathrm{~km} 2$ and the ratio between banking services and area coverage (Wibowo 2013).

The financial service gap is very clearly seen by region in Indonesia. In West Papua and Papua, a banking service serves a radius of more than $1000 \mathrm{~km} 2$. The long distance that must be taken by the community to enjoy banking services is also complicated by terrain conditions and lack of infrastructure.

The disparity in banking services also occurs at the sub-district level. The highest level of banking services at the sub-district level is in Jakarta, on average each sub-district is served by 91 bank offices. Whereas in Papua the level of banking services is the lowest, where one sub-district is only served by less than one bank office or not all sub-districts have banking services. The disparity in bank services causes the creation of financial exclusion conditions and even leads to financial exploitation (Wibowo 2013). In addition to infrastructure constraints, limited financial services are also influenced by income factors that create social barriers that are not always related to economic activities.

The perception that is built on banking services aimed at the rich is a barrier, especially coupled with the complexity of financial service registration procedures such as KTP and financial history, causing productive poor people who are not equipped with official documents do not get services. This is experienced by urban workers in the informal sector, as well as workers in the formal sector such as laborers.

In addition, gender inequality is also one of the factors where there is a perception that women have a greater level of risk than men or the perception of family heads is more deserving of credit, which makes the proportion of women who get credit far lower than men.

Efforts to implement inclusive finance in Indonesia can be carried out through at least three channels, namely microfinance, social security payments and the use of digital financial services (branchless banking). So far, microfinance is considered to have helped the micro industry to gain access to capital to create jobs and wealth. Micro and medium enterprises in Indonesia are one of the pillars driving the economy. With more than 51 million business units or $99.9 \%$ of the total business in Indonesia, UMK absorbs more than $97 \%$ of the workforce with a contribution of more than 55\% of GDP and an investment value of 53\% of total investment in 2008 (BPS 2008 ) In addition, with the increasingly rigid labor market in Indonesia, more and more productive age workers are plunging into the informal sector which then enlarges the target of financial services.

However, financial institutions, especially banks in Indonesia, are even more challenging to access by micro and small businesses because they are considered too risky, as a result of adherence to the application of the principle of prudence, with the aim that the 1998 crisis does not recur. Banking in Indonesia is increasingly implementing large amounts of re-creation, especially in micro-business loans that create both price and non-price barriers to expanding access to micro-businesses dominated 
by low-income groups. In this case, Rosengard and Prasenyantoko (2013) describe Indonesia's financial sector as having two twin paradoxes: (1) Indonesia which has been the leader in microfinance for the past 25 years in fact access to microfinance has actually declined, and (2) commercial banks in Liquid, solvent and profitable Indonesia as a result of the improvement of the national financial system is actually not responsive in not meeting sufficient demand through providing access for micro-businesses in the absorption of credit.

Meanwhile, in terms of banking, MSEs even though they have great potential in terms of numbers, but have a relatively high risk (Rahayu, 2005). The characteristics of most SMEs in Indonesia include still not running their business with modern management principles, not having an official business entity, and limited assets owned. In fact, the larger the scale of business, the credit risk will decrease even though the average potential margin obtained will be even more significant.

Besides, the expansion of banking financial services can also be done through digital financial services. The development of digital services through branchless banking is more accessible to realize because of the geographical and administrative barriers that have been faced by the poor and in the interior, which can be eliminated. The existence of bank accounts in addition to reaching savings services also provides a basis for them to access business credit. For example, the transfer of social security payments through digital services will directly encourage inclusive finance for beneficiaries who can save both parts of withdrawals and other deposits, build financial histories to access credit services, and encourage non-cash transactions (Joyce 2015).

The Financial Inclusion Strategy in Indonesia. A large number of un significant factors prompted the Government to issue a Presidential Regulation to establish the National Strategy for Inclusive Finance (SNKI) in early September 2016 through the National Financial Inclusion Strategy Pillar concept (Figure 1). The aim is to encourage economic growth, accelerate poverty reduction, reduce inequalities between individuals and between regions in order to realize the welfare of the Indonesian people.

The inclusive financial policy framework as a national strategy is made by various stakeholders. This strategy targets explicitly the poor who have been identified according to several categories. The government believes that through SNKI it will be able to increase the Inclusive Financial Index to $75 \%$ by 2019 . To reach the 75 percent target in 2019 , the government sets several pillars as support for SNKI. The first is financial education involving OJK, government, and BI. Second, community property rights (public property rights). Most of these pillars are the certification of community land with the backbone of the ATR / BPN Ministry.

The third pillar is the intermediation facility and financial distribution channel which will be carried out more by the FSA. Fourth, financial services in the government sector. Here, social assistance will be developed through financial inclusion. Transformation of subsidies from the government will also enter through this pillar with the Ministry of Social and BI's backbone. The final pillar is related to consumer protection through the cooperation of OJK, BI, and the government.

BI has an inclusive financial target of $75 \%$ of banked people in 2019 targeting $40 \%$ of low-income people, micro and small businesses (SMEs), and across groups (migrants, women, PMKS, and students). While the development of MSMEs is carried out with a local economic development approach. The inclusive financial education program aims to introduce access and increase financial knowledge to encourage formal financial services in order to improve welfare while efforts to support the development of payment and financial service innovations are carried out with fintech office development.

OJK as a strategic authority explicitly assigned to deal with matters of inclusion and financial literacy supports the various efforts of the Financial Services Institution (LJK) to increase national financial inclusion through various financial innovations such as the development and incentives of various available financial products and services that are easily accessible to the public. OJK's inclusive financial activities will target community groups that have not been fulfilled by formal financial services, namely low-income communities, micro and small business people, and communities from 
across groups including migrant workers, women, community groups with social welfare problems, communities in disadvantaged areas and also student groups.

OJK has implemented various financial inclusion activities which include the Regional Access to Finance Acceleration Team (TPAKD), Officeless Financial Services in the Context of Inclusive Finance (Laku Pandai), Student Savings (SimPel/SimPel iB), microinsurance, Microfinance Services (Micro Practice) as well as various financial access improvement programs that fit the needs of the community. Besides, to improve the culture of saving, OJK programmed to encourage the National Savings Movement (GNM) with a broader scope. The implementation of GNM includes the banking industry (saving on simple/simple iB), capital markets (let us save shares and let us invest in mutual funds), mortgages (let us save gold), and pension funds (saving for the future).

The Role of Financial Inclusion in Equal Income and Poverty Reduction in Eastern Indonesia. Many efforts that have been made by several relevant authorities must have been able to provide visible results at least through several indicators or data related to the targets and objectives of various policies that have been implemented.

\section{Research Methodology}

This research is an explanatory research. A type of data used in this research is secondary data collected by survey. This research employs financial inclusion index formula, Gini Ratio Index and descriptive statistics.

\section{Result and Discussion}

There are three determinants of financial inclusion that can be traced to development one by one which can then be analyzed concerning the impact on targeted economic aspects, such as aspects of income growth and equity, especially in efforts to alleviate poverty, especially in cases in several provinces in Eastern Indonesia - restricted to Sulampua region, covering 10 major provinces, namely 6 provinces in the Sulawesi archipelago, two provinces in Maluku and two provinces of Papua.

The first indicator relates to an overview of the aspects of community penetration in the region through an analysis of the pattern of the development of the number of community accounts in the banking sector, especially both as depositors and as credit customers, as can be illustrated in Table 1 .

Table 1. Banking Services Penetration

1. Penetrasi: Jumrek DPK/Penduduk
\begin{tabular}{|l|c|c|c|c|c|}
\hline Propinsi & $\mathbf{2 0 1 6}$ & $\mathbf{2 0 1 7}$ & $\mathbf{2 0 1 8}$ & Pola Kecendrungan & Pola Kecendrungan \\
\hline Sulawesi Selatan & 0.759 & 0.939 & 1.007 & & \\
\hline Sulawesi Barat & 0.450 & 0.659 & 0.716 & & \\
\hline Sulawesi Utara & 0.768 & 0.953 & 1.020 & & \\
\hline Sulawesi Tengah & 0.601 & 0.760 & 0.826 & & \\
\hline Sulawesi Tenggara & 0.643 & 0.848 & 0.903 & & \\
\hline Gorontalo & 0.583 & 0.794 & 0.902 & & \\
\hline Maluku & 0.620 & 0.841 & 0.895 & & \\
\hline Maluku Utara & 0.538 & 0.679 & 0.726 & & \\
\hline Papua & 0.657 & 0.789 & 0.820 & & \\
\hline Papua Barat & 0.896 & 1.130 & 1.179 & & \\
\hline Rata-rata & $\mathbf{0 . 6 5 2}$ & $\mathbf{0 . 8 3 9}$ & $\mathbf{0 . 8 9 9}$ & & \\
\hline
\end{tabular}

Source: Processed data

From this description, it can be seen that in general, community penetration as measured by the number of their accounts as saver customers continues to increase significantly, as indicated by the average number in 2018, the number has reached almost 90 percent of productive residents who have accounts in banks where previously only 65 percent. Likewise, the number of accounts of the community as debtors continues to improve, except in two cases of provinces that seem to have a declining trend pattern, namely the case of North Sulawesi and Papua. June 2018 reached 92 percent wherein 2016 only 87 percent. 
The second indicator of determining financial inclusion is the availability of banking services that can be seen from the development of the number of banks serving deposits and loans from the public. The following table shows that although many community accounts have been modeled, apparently the number of banks serving is still relatively limited, even though the number is increasing, but on average only around 10 percent of the population, or it can be said that each bank on average serving a population of up to 10,000 people where banks must serve the majority in West Sulawesi and Gorontalo.

Table 2. Banking Service Penetration or Accessibility

1. Penetrasi: Jumrek Kredit/Penduduk
\begin{tabular}{|l|r|r|r|l|l|}
\hline Propinsi & 2016 & 2017 & 2018 & Pola Kecendrungan & Pola Kecendrungan \\
\hline Sulawesi Selatan & 0.114 & 0.120 & 0.125 & & \\
\hline Sulawesi Barat & 0.064 & 0.070 & 0.075 & & \\
\hline Sulawesi Utara & 0.117 & 0.119 & 0.117 & & \\
\hline Sulawesi Tengah & 0.090 & 0.093 & 0.095 & & \\
\hline Sulawesi Tenggara & 0.088 & 0.091 & 0.094 & & \\
\hline Gorontalo & 0.111 & 0.114 & 0.116 & & \\
\hline Maluku & 0.066 & 0.069 & 0.071 & & \\
\hline Maluku Utara & 0.063 & 0.065 & 0.065 & & \\
\hline Papua & 0.064 & 0.064 & 0.063 & & \\
\hline Papua Barat & 0.095 & 0.095 & 0.096 & & \\
\hline Rata-rata & 0.087 & 0.090 & 0.092 & & \\
\hline Source: Proce & & & & & \\
\hline
\end{tabular}

Source: Processed data

Based on these data, there is an exciting thing that can be observed, that it seems that on average there is a tendency to reduce the number of banks operating, especially in South Sulawesi, Gorontalo, Maluku, and Southeast Sulawesi, although there are also other provinces which tend to increase, namely in Papua and Central Sulawesi. Of course, there are many reasons for this to occur, which seems to be the authority that needs to react, because, after all the population increases, the need for an increase in the number of banks is undoubtedly increasing, especially since the number of banks that are still relatively lacking.

Table 3. Availability or Availability of Banking Services

\begin{tabular}{|c|c|c|c|c|c|c|c|c|}
\hline \multicolumn{9}{|c|}{ 2. Indikator Ketersediaan: Jumlah Bank/Penduduk } \\
\hline Propinsi & 2013 & 2014 & 2015 & 2016 & 2017 & 2018 & Pola Kecendrungan & Pola Kecendrungan \\
\hline Sulawesi Selatan & 0.104 & 0.103 & 0.102 & 0.101 & 0.100 & 0.099 & & 뭄므- \\
\hline Sulawesi Barat & 0.060 & 0.059 & 0.058 & 0.061 & 0.060 & 0.059 & 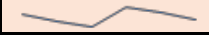 & 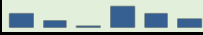 \\
\hline Sulawesi Utara & 0.111 & 0.110 & 0.119 & 0.121 & 0.119 & 0.118 & & $-\ldots-\square \square \square$ \\
\hline Sulawesi Tengah & 0.058 & 0.057 & 0.057 & 0.097 & 0.096 & 0.094 & & $--\ldots \square \square \square$ \\
\hline Sulawesi Tenggara & 0.079 & 0.097 & 0.094 & 0.093 & 0.089 & 0.088 & 1 & 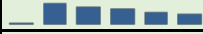 \\
\hline Gorontalo & 0.095 & 0.093 & 0.096 & 0.096 & 0.069 & 0.068 & & $\square \square \square \square-\ldots$ \\
\hline Maluku & 0.085 & 0.089 & 0.089 & 0.087 & 0.086 & 0.086 & 1 & - ㅁㅁㄷㅡ. \\
\hline Maluku Utara & 0.080 & 0.078 & 0.078 & 0.077 & 0.080 & 0.074 & & ㅁㅁㅁㄷㅡ. \\
\hline Papua & 0.086 & 0.084 & 0.090 & 0.102 & 0.124 & 0.122 & & $---n \square$ \\
\hline Papua Barat & 0.150 & 0.160 & 0.174 & 0.237 & 0.229 & 0.224 & & $=--\square \square \square$ \\
\hline Rata-rata & 0.091 & 0.093 & 0.096 & 0.107 & 0.105 & 0.103 & 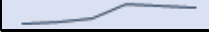 & $--\infty \square \square \square$ \\
\hline
\end{tabular}

Source: Processed data

The third indicator that needs to be identified as a determinant of financial inclusion is the usability aspect of the existence of the banking system. This can be measured by comparing the size of community deposits and the amount of credit channeled by banks to the regional income of each province (GRDP).

The following table shows that the ratio of public savings to GRDP is still minimal, although it has tended to increase, but the last two years have decreased evenly in Sulampua KTI, so that it has only reached 19.22 percent. The provinces that experienced the highest position in this ratio, Maluku, reached above 30 percent, followed by North Maluku, North Sulawesi and South Sulawesi in the 
range of above 20 percent. Three provinces experienced a decline in this ratio in the last three periods, namely South Sulawesi, North Sulawesi, Maluku, and Papua.

Table 4. Usability or Utility of Banking Services: DPK / GRDP

\begin{tabular}{|c|c|c|c|c|c|c|c|c|c|c|}
\hline \multicolumn{3}{|c|}{ 3. Indikator Kegunaan: DPK/PDRB } & & & & & & & \multirow{2}{*}{\multicolumn{2}{|c|}{ Pola Kecendrungan Pola Kecendrungan }} \\
\hline Propinsi & 2010 & 2011 & 2012 & 2013 & 2014 & 2015 & 2016 & 2017 & & \\
\hline Sulawesi Selatan & 21.61 & 23.00 & 23.65 & 23.46 & 22.34 & 23.23 & 21.93 & 21.10 & 工 & 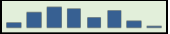 \\
\hline Sulawesi Barat & 10.19 & 12.25 & 11.75 & 11.94 & 11.03 & 11.57 & 10.77 & 11.34 & $\ldots$ & 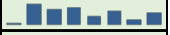 \\
\hline Sulawesi Utara & 24.76 & 25.77 & 25.62 & 24.85 & 24.16 & 23.42 & 21.24 & 21.68 & $\infty$ & 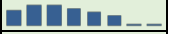 \\
\hline Sulawesi Tengah & 13.66 & 14.84 & 15.38 & 15.06 & 15.46 & 15.74 & 14.42 & 14.61 & 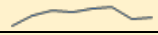 & 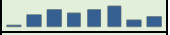 \\
\hline Sulawesi Tenggara & 12.23 & 14.87 & 15.00 & 15.22 & 14.40 & 16.44 & 15.22 & 15.65 & $\sim$ & 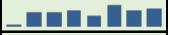 \\
\hline Gorontalo & 10.41 & 14.23 & 13.92 & 13.17 & 13.36 & 13.72 & 12.95 & 13.23 & 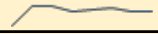 & 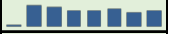 \\
\hline Maluku & 30.74 & 33.02 & 34.41 & 34.49 & 33.96 & 36.21 & 32.63 & 32.09 & $\approx$ & 듬ㅁ므므. \\
\hline Maluku Utara & 16.92 & 22.57 & 23.06 & 22.91 & 22.13 & 24.01 & 22.23 & 21.59 & 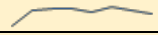 & 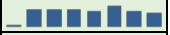 \\
\hline Papua & 17.78 & 21.62 & 23.33 & 23.35 & 24.49 & 22.68 & 21.35 & 20.06 & $=$ & 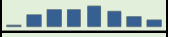 \\
\hline Papua Barat & 13.93 & 16.19 & 17.74 & 21.08 & 22.14 & 20.73 & 20.31 & 20.89 & $=$ & $=-\sin$ \\
\hline Rata-rata & 17.22 & 19.84 & 20.39 & 20.55 & 20.35 & 20.78 & 19.30 & 19.22 & $\tau$ & - \\
\hline
\end{tabular}

Source: Processed data

On the other hand, the ratio of credit to GDP seems to tend to increase but is very weak, which is only in the range of 25 percent in 2010 and has only increased to 26.70 percent for seven years. A number is a relatively small change. Besides that, the concern is that this ratio tends to continue to decline in some large provinces, especially in South Sulawesi and North Sulawesi, including in West Sulawesi and Maluku. However, there are also provinces that have experienced an increase in their ratios, namely Southeast Sulawesi, Gorontalo, North Maluku, and West Papua.

As in the previous case, with the development of the data from the last two types of ratios, the relevant authorities, especially the OJK and BI need to find out, especially about the causes of the two ratios in several strategic provinces because they should be favored, because otherwise, the issue is not suitable for efforts to improve financial inclusion which continues to be intensified by the monetary and financial authorities themselves.

Table 5. Use of Banking Services: Credit / GRDP

\begin{tabular}{|c|c|c|c|c|c|c|c|c|c|c|}
\hline \multicolumn{11}{|c|}{ 3. Indikator Kegunaan:Kredit/PDRB } \\
\hline Propinsi & 2010 & 2011 & 2012 & 2013 & 2014 & 2015 & 2016 & 2017 & Pola Kecndrungan & Pola Kecndrungan \\
\hline Sulawesi Selatan & 33.48 & 34.68 & 30.98 & 31.47 & 30.23 & 30.13 & 29.37 & 29.11 & & 口ローローーー- \\
\hline Sulawesi Barat & 20.34 & 21.19 & 19.18 & 20.63 & 19.60 & 19.92 & 21.90 & 24.04 & & -E_-_-口 \\
\hline Sulawesi Utara & 39.31 & 40.78 & 36.74 & 37.10 & 36.16 & 36.18 & 35.88 & 35.43 & & Da-ーー-- \\
\hline Sulawesi Tengah & 27.74 & 28.91 & 25.84 & 26.98 & 26.97 & 27.90 & 25.59 & 24.79 & & 口प_B口_- \\
\hline Sulawesi Tenggara & 19.28 & 21.91 & 19.39 & 22.67 & 22.29 & 22.09 & 23.67 & 23.04 & $\curvearrowright$ & 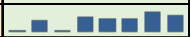 \\
\hline Gorontalo & 33.02 & 36.05 & 32.39 & 35.83 & 36.73 & 36.31 & 35.42 & 36.10 & & - \\
\hline Maluku & 31.54 & 31.55 & 27.75 & 30.01 & 28.57 & 28.73 & 30.34 & 32.49 & & $a_{\text {_E_- }}$ \\
\hline Maluku Utara & 24.27 & 25.78 & 22.98 & 23.27 & 22.76 & 22.73 & 22.91 & 24.32 & & $a_{-}---n$ \\
\hline Papua & 10.61 & 13.86 & 13.57 & 15.35 & 15.76 & 15.50 & 14.65 & 14.39 & & 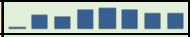 \\
\hline Papua Barat & 10.90 & 13.31 & 13.02 & 14.97 & 15.93 & 17.80 & 22.22 & 23.32 & & -ーー・日日ᄆ \\
\hline Rata-rata & 25.05 & 26.80 & 24.18 & 25.83 & 25.50 & 25.73 & 26.19 & 26.70 & & 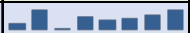 \\
\hline
\end{tabular}

Source: Processed data

In terms of measuring financial inclusion indicators, OJK and BI have conducted surveys to measure the level of financial inclusion for all provinces as shown in the following figure. It can be seen that the financial inclusion index in Indonesia has increased significantly, from an average value of 59.74 percent in 2013 to 67.82 percent. However, this is clearly still far from the expectations of all parties, including the government targeting 2019 reaching 75\%. Following the region, the financial inclusion index increased on average, wherein 2016, it was recorded in Sulampua region, the highest financial inclusion index in North Sulawesi, followed by South Sulawesi, above 68 percent higher than the national level whereas the province with the smallest index is West Papua below 60 percent, where other provinces are above 62 percent. 
Figure 1. Indonesian Financial Inclusion Index and Sulampua

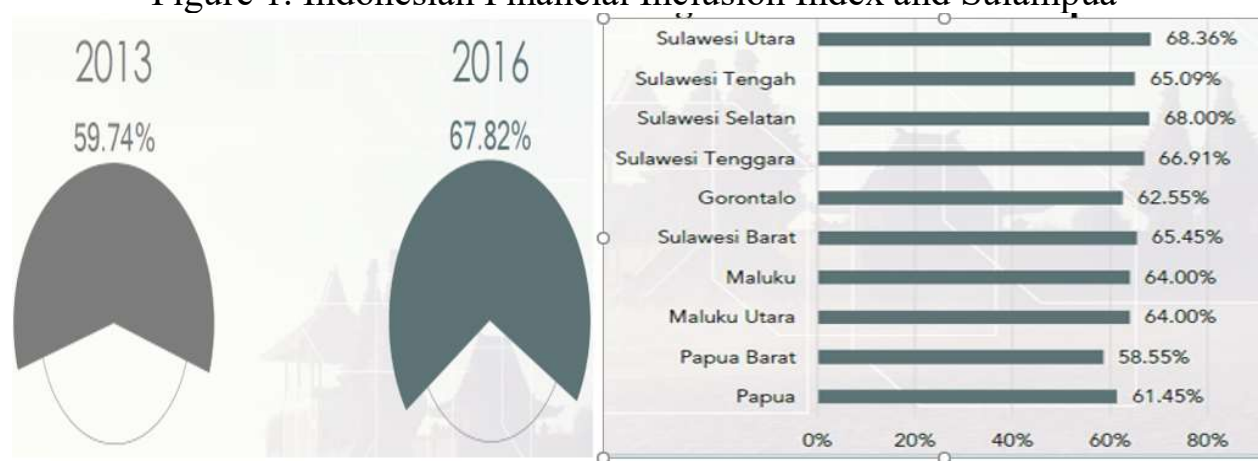

Source: OJK

The data shows that serious efforts clearly need to be carried out even though it is not easy as a result of the many problems faced, if indeed we want our society to be able to optimally utilize banking services, especially to increase their productive activities. So that they can improve their quality and standard of living equitably, through the creation of work opportunities and optimization efforts so that efforts to reduce inequality or equalize income and poverty alleviation efforts can be realized. The following figure explains the conditions faced by the community in Sulampua towards the national, specifically concerning the role of the banking sector in terms of aspects of economic growth, income inequality, and poverty.

Figure 2. The Role of the Banking Sector on Economic Growth, Gini Ratio and Poverty in Sulampua, KTI. 2010-2017

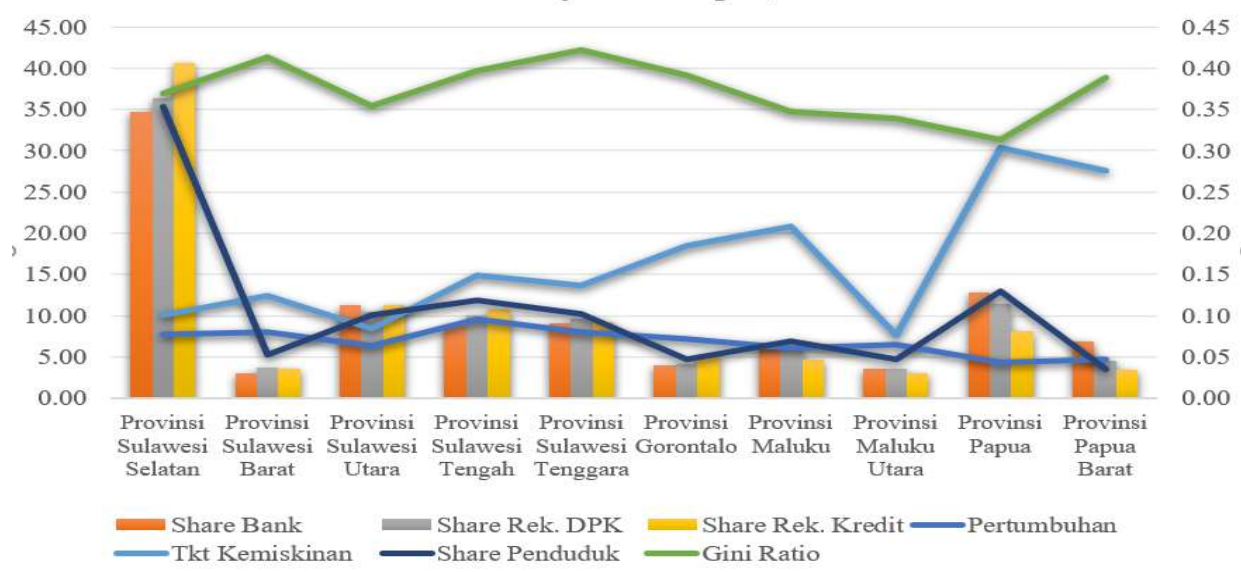

Source: Processed data

The figure shows that on average South Sulawesi compared to other provinces in Sulampua occupies the highest position in several existing share indicators, especially on the aspect of the population, and aspects of the banking sector in the number of banks, deposits, and credit, all of which are above 35 percent. In this case, followed by North Sulawesi and Papua, except the credit share, then Central Sulawesi and Southeast Sulawesi, while the smallest share in West Sulawesi and North Maluku. The description of aspects of growth, poverty and Gini Ratio, South Sulawesi is also still in a relatively reasonable and proportional ratio followed by North Sulawesi. As for other provinces, there is a lack of proportional relationship between the share indicators that are related, and some are quite alarming, namely sharing high levels of poverty and poverty, such as in the cases of Gorontalo, Maluku, Papua, and West Papua.

This indicates that it seems that the role of the banking sector has a direct or no influence on the development of several real sector indicators in each province. For example the case of South 
Sulawesi, that with the large share of the role of the number of banks, the number of deposits and credit, the economic growth rate is relatively high and stable, the poverty rate is relatively low, even though the Gini ratio remains high. Likewise with the North Sulawesi case, so it seems that there is a linkage between the banking sector's role in influencing real sector movements from the province. Including in the case of Central Sulawesi, Southeast Sulawesi, Maluku, and Papua provinces.

Furthermore, if we correctly analyze by linking directly between determinants of financial inclusion factors with real economic sector indicators, such as economic growth, aspects of income equity as measured by the Gini Ratio index, as well as aspects of poverty levels, then it seems from Figure 6 below, at a glance, it can be found that there are several patterns of relationships or linkages between these indicators.

In the case of South Sulawesi, for example, it appears that financial inclusion indicators, namely indicators of community access to the banking sector both save funds and credit are quite high, so the penetration of financial services on credit is relatively high and proportional, with indicators of availability and especially financial services penetration on deposits relatively low. It can be seen from some of the financial inclusion indicators that there is a connection between the relationship between financial inclusion indicators with real sectors whose patterns can differ from those expected. In general, it was found a relationship that two financial inclusion indicators, penetration tends to increase, while indicators of the availability of financial services tend to decline or improve, but indicators of declining use of deposits and credit. In relative terms, the impact, economic growth, Gini Ratio, and poverty rates declined. This means that qualitatively for the case of South Sulawesi it can be said that the role of financial inclusion, particularly banking, can be considered to have a significant role in influencing the real sector, particularly efforts to equalize income and alleviate poverty.

Figure 3. Relationship between Financial Inclusion Indicators, Growth, Gini Ratio, and Poverty in Sulampua, KTI, 2010-2017

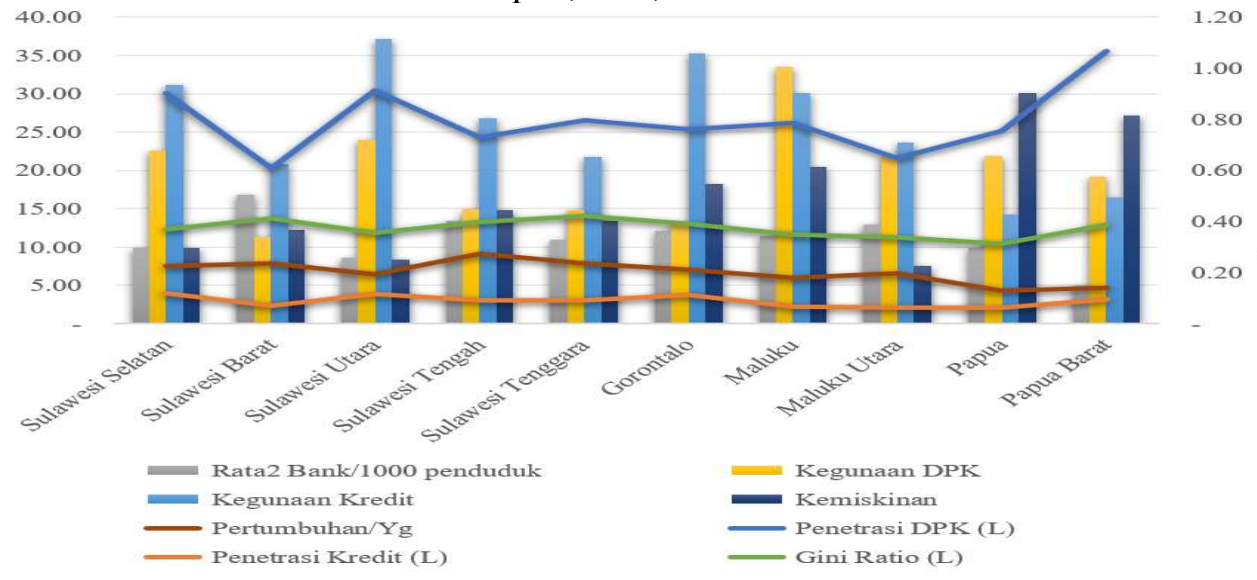

Source: Processed data

In the case of West Sulawesi, there seems to be something similar to the case of South Sulawesi, although there are some that are not good, namely the indicator of the availability of a more significant number of banks. The indicator of the use of deposits and credit grows in proportion but in a lower value. Indicators of penetration of financial services for deposits and credit tend to increase even though credit penetration indicators are relatively small. The availability indicator tends to decline or improve, but the usability indicator has a poor declining pattern. The impact, indirectly, economic growth, Gini Ratio, and poverty rates tend to decline. Paying attention to this information, then by qualitatively analyzing it can be seen that there is a relationship between the financial inclusion indicators for changes in real sector indicators directly or indirectly. 
In the case of North Sulawesi, bank availability indicators are relatively small or better than South Sulawesi and West Sulawesi, as indicators of the use of deposits and credit are particularly high over South Sulawesi and the pattern tends to increase. Although the Indicator of credit penetration is relatively small under South Sulawesi and tends to decline. As a result, the patterned economic growth of tendring has increased, with the poverty rate likely to decline, but the Gini ratio tends to increase. This means that there is a director no influence from the development of financial inclusion indicators on income equity and poverty level indicators.

Central Sulawesi is a province that has a position of financial inclusion index, especially higher or fewer availability indicators from two provinces of West Sulawesi and North Sulawesi, with a tendency to increase. Although the indicator of usability is relatively high for both but tends to decline. However, the impact, economic growth, Gini Ratio, and poverty levels have a declining adverse pattern. So that the impact is indirect, economic growth decreases, but the Gini ratio index and poverty decline or improve.

Southeast Sulawesi is a province that is more or less the same as the condition of its financial inclusion indicators with Central Sulawesi, with indicators of the availability of financial services smaller or better, but with indicators of credit usefulness more or less the same but still more indicators of the use of deposits. DPK and credit penetration indicators have an increasing pattern as in the indicators of DPK and credit or good use, although indicators of bank service availability have a declining pattern. As a result, economic growth has a declining trend pattern but with a pattern of trends the Gini Ratio index increases, but the pattern of trends in poverty levels decreases.

Gorontalo is a province that has some poor financial inclusion indicators compared to Central Sulawesi and Southeast Sulawesi. However, the financial penetration index is still higher or better, both of which have an increasing trend pattern. The index of the usefulness of financial services is quite high or sound, and tends to increase, along with its availability or increasing index. Indirect impacts, economic growth indeed tends to decline, but the poverty rate has also tended to decline, but it is accompanied by a trend towards an increase in the Gini Ratio index.

Maluku is a region that has relatively good determinants of financial inclusion, with a high index of the use of financial services, especially the index of DPK use compared to credit. However, the index of DPK penetration is high or not good even though the credit penetration index is limited, but both have an increasing trend pattern. The servant's willingness index is relatively high, but the pattern of development trends is relatively stable. However, the use of deposits index tends to decline even though the credit usefulness index tends to increase. As a result, economic growth is relatively low but tends to increase, with a high poverty rate but tends to decline, but with a high Gini Ratio index which tends to increase.

The pattern of movements in the North Maluku financial inclusion index is more or less the same as Maluku, with a few exceptions, which are still limited indicators of service availability but are quite low in poverty. DPK penetration index is relatively high compared to credit, but both tend to increase patterns. Limited availability indicators accompanied by a contemporary trend of declining include indicators of credit availability, while the indicator of the availability of deposits is quite good and stable. As a result, economic growth is relatively low but tends to increase, accompanied by a decline in poverty levels and the Gini Ratio index even though the value is still high.

The main characteristic of Papua is the highest level of poverty in Indonesia. In terms of determinants of financial inclusion, Papua has a similar pattern of higher use of DPK indicators such as Maluku. The indicator of DPK penetration is quite high and has a tendency to increase, but with a relatively small position of credit penetration indicator and the pattern tends to decline. Although the indicator of service availability is relatively limited, the pattern tends to continue to increase or not good, especially with the indicator of the use of deposits, which tends to decrease compared to the indicator of credit use which tends to increase. As a result, economic growth tends to decline, accompanied by a tendency to decrease the poverty rate, but with a tendency to increase the Gini Ratio index. 
Finally, West Papua, including the region with the highest number of poor people with a high level of Gini Ratio, but with a pattern of indicators for the use of more massive deposits such as Maluku and Papua. Indicators of service availability are relatively poor because they are relatively high and tend to increase, but with high DPK penetration indicators but a small credit penetration indicator. Both of these indicators have a pattern of development trends that increases or improves. Indicators of the availability of banking services are relatively low or right but tend to increase or be wrong, which is accompanied by indicators of the usefulness of credit which tends to decline even though the recovery is still functional. While the indicator of the use of deposits is quite useful because it is high but tends to decline. As a result, economic growth tends to decline, with the Gini Ratio index stable but relatively high, but with a pattern of decreasing poverty levels.

\section{Conclusion}

Financial inclusion provides an opportunity for all community groups to be able to take advantage of financial services without exception in various regions, especially in Eastern Indonesia. It is hoped that the policy will have an indirect impact on economic growth and long-term development because it works not only in groups of people who already have access to financial services, but most importantly can reach the poor who are engaged in productive sectors, especially the informal sector and the most MSMEs. Many people in Indonesia.

The government has taken steps and efforts for these interests through the implementation of a national financial inclusive strategy (SNKI). SNKI strategically targets productive poor groups who have the potential to reach financial services through the supply and demand side approach. However, SNKI itself still seems to be not optimal in planning especially the implementation, so that the impact cannot yet be measured, especially felt optimally by the community.

This is reflected in the results of a brief study conducted, which showed that in several areas in Sulampua KTI in particular, there were some planned plans that could not be known with certainty in the mechanism by most people. So it is still difficult to accurately measure the impact of the policies implemented so that this study is only able to reveal facts about measures that determine financial inclusion in general in relation to the tendency of the direction of real sector development which is the normative target of financial inclusion policies, mainly economic growth, the Gini Ratio index, and poverty levels.

From the results of the analysis carried out, in general, it can be said that the exact shape and pattern of relationships that have occurred can be determined from several observed variables. Because of the results, several relationships are expected to be conceptually possible, patterns and mechanisms for their relationship cannot be found or established so that we need a better analysis tool or method.

\section{References}

Allen F, Kunt DA, Klapper L, Peria MSM. 2012. The Foundations of Financial Inclusion: understanding Ownership and Use of Formal Accounts. Policy Research Working paper 6290, Development Research Group, Finance, and Private Sector Development Team, World Bank.

Ali, I., \& Son, H. (2007). Measuring Inclusive Growth. Asian Development Review, vol. 24, no. 1, 11-31.

Anand, R., Mishra, S., \& Peiris, S. (2013). Inclusive Growth: Measurement and Determinants. $\mathrm{WP} / 13 / 135$.

Beck T, Kunt AD, Peria MSM. 2006. Reaching Out: Access to and Use of Banking Services Across Country. World Bank Working paper

Cheng X, Degryse H. 2006. The Impact of Bank and Non-Bank Financial Institutions on local Economic Growth in China

Kelkar, V. (2010). Financial Inclusion for Inclusive Growth. 39(1): 55-68.

Rosengard, J. K., \& Prasetyantoko, A. (2011). Regulatory Constraints to Financial Inclusion in Indonesia. Asian Economic Policy Review. 
Sarma, M. (2012). Index of Financial Inclusion - A measure of financial sector inclusiveness. Sarma, M., \& Pais, J. (2008). Financial Inclusion and Development: A Cross Country Analysis.

Sarma Mandira, Pais Jasim. 2012. Financial Inclusion and Development: a Cross country Analysis. World Bank Working paper

Sinclair, S. (2001). Financial Exclusion: An Introductory Survey. Edinburgh: CRISIS/Heriot-Watt University. 